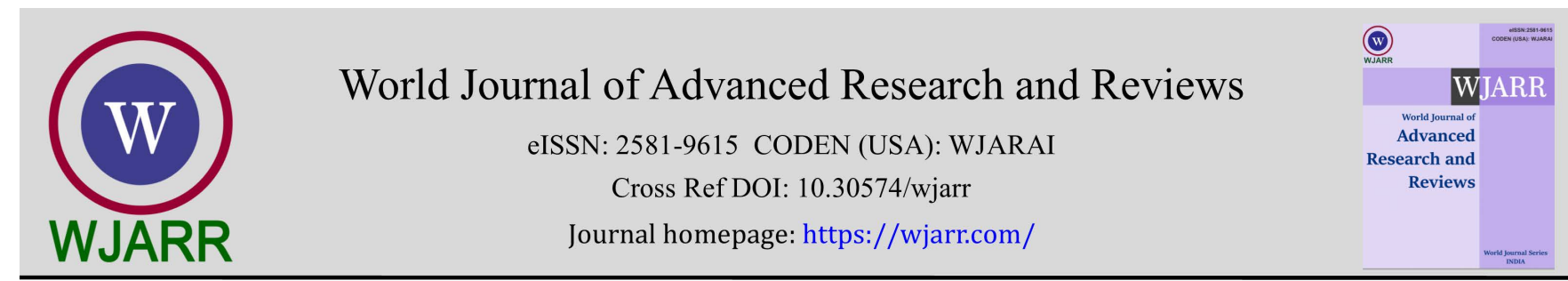

(REVIEW ARTICLE)

Check for updates

\title{
COVID-19 Vaccines: Systematic review
}

Heena Bholaram Choudhary *, Indra Hemaram Sirvi, Yash Rajendra Bamb, Priyanka Rajendra Bamb and Rohan RajkumarPatekar

Rasiklal M. Dhariwal Institute of Pharmaceutical Education and Research; Chinchwad, Pune-411019, MH-India.

World Journal of Advanced Research and Reviews, 2021, 10(01), 143-155

Publication history: Received on 20 February2021; revised on 01 April 2021; accepted on 03 April 2021

Article DOI: https://doi.org/10.30574/wjarr.2021.10.1.0118

\begin{abstract}
World facing pandemic challenges of SARS-Co-2 (Severe Acute Respiratory Syndrome Corona Virus 2). Tyrrell and Bynoe identified first strain of human corona virus in 1965. Infection was originated from Wuhan city of China on November 2019. Virus officially named as COVID-19 which causes respiratory tract infections in humans. Preliminary symptoms like chest pain with difficulty in breathing, reduced in systemic oxygen level, cough and fever. At present, the majority of the pharmaceutical companies were in race to developing antiviral drug and vaccines against COVID-19. Industries conducting the experiment and clinical trial of various vaccines to ensure effectiveness and safety on human. Several of them were documentation for patent, authorization of clinical trial and marketing. We provide an overview of Covid-19 history, types of vaccine and mechanism of actions, current future therapeutic drugs and patents. Relative with the mechanism of actions such as inactivated vaccine, vector vaccines, DNA and RNA based vaccine and antiviral drugs already entered in (Phase II and III) clinical trials.
\end{abstract}

The systemic study specified brief summary of various vaccines. Current status of clinical trial, safety and effectiveness according to ICH guidelines. A major adverse interaction with their toxicity study. The information of approved which give opportunity for upcoming scientist to improve the quality, and minimize the adverse effects. Scientist may face challenges during the post marketing clinical trial. This pandemic has provided various scopes for researchers to develop vaccine and antiviral drugs.

Keywords: SARS COV-2; Covid - 19; vaccine; virus; Covaxin; Pfizer.

\section{Introduction}

Corona virus caused an infectious disease by severe acute respiratory syndrome (SARS-COV-2). It is a group of RNA viruses that causes diseases in humans, mammal and birds [1]. Covid-19 first case was being identified in Wuhan, China, in November 2019 [2, 3]. In human they cause respiratory tract infections. Covid-19 constituents on the family of corona virus and subfamily Coronavirinae. It is an enveloped or enclosed type virus with positive sense single stranded RNA genome and nucleocapsid of helical symmetry [4]. About 26-32 Kilo bases size of genome of the corona virus. In electron micrographs corona virus structure will be seen as large, club shaped or spherical shape structure and spikes present in their structure [4]. Its structure will be seen same as to solar corona structure. Covid-19 affects people in different ways. Symptoms will be seen in mild to moderate condition such as Dry cough, tiredness, headache, loss of taste, fever. Loss of speech, loss of movement, Difficulty in breathing, chest pain will be serious symptoms seen in Covid-19 [1, 2, 3].

${ }^{*}$ Corresponding author: Heena Bholaram Choudhary

Rasiklal M. Dhariwal Institute of Pharmaceutical Education and Research; Chinchwad, Pune-411019, MH- India. 


\section{History of (SARS-COV-19)}

In 1965 Firstly Identified Human Corona Virus By the Scientists [5, 6]. Main Symptoms identify human corona virus is Common Cold [6]. Again New Corona Virus identified in 2019 in Wuhan, China Market. China is first Country of the world identify the First patient or Virus Infected patient $[5,6]$. Researcher said that, it's a big Familiar disease and again Common cold main symptoms present infected patient [5]. Newly identify Corona virus officially name as SARS-CoV-2 (Severe acute respiratory syndrome) by International Committee on Taxonomy of Virus researcher said novel corona virus originated in bats [5]. Main contained identify researcher is the Virus is rapidly transfer to animals to human body. And human body to again next human body continuously transforms because this virus is very dangerous, rapidly to transform one body to another body. Corona virus is fifth Pandemic disease. Shortly Pandemic Information mention in (Table 1). As per WHO on 2020 December 10, Active Case $69.1 \%$ and mortality rate $1.57 \%$ all over world.

Table 1History of pandemic disease.

\begin{tabular}{|l|l|}
\hline 1918 & Spanish Flu (H1N1) (Influenza A Virus) [9] \\
\hline 1957 & Asian Flu (H2N2) (Influenza A virus) [9] \\
\hline 1968 & Hong Kong Flu (H3N3) (Influenza A Virus) [7] \\
\hline 1976 & Zaire Ebola virus (EBOV) \\
\hline 2009 & Pandemic Flu (H1N1) (Influenza A Virus) [10] \\
\hline 2019 & Covid-19 (SARS-COV-2) Corona virus \\
\hline
\end{tabular}

\section{Vaccines}

\subsection{Pfizer BioNTech Covid-19 vaccine}

Pfizer BioNTech has, like Moderna, spread a vaccine that uses mRNA to bring about the immune system to identify the corona virus. Pfizer vaccine needs to store at -70 degree Celsius. BNT162b2 was $90 \%$ effective against Covid 19 [11, $15,16]$. The vaccine injected into human cells to produce the SARS-COV -2 spike protein the immune system main target against corona virus.

\subsubsection{Mechanism}

This vaccine can be developed by mRNA.The mRNA carries information between different parts of a cell, providing instruction like which protein to make. BNT162b2 uses messenger RNA that report one of the spike protein that dotted the outer surface of SARS-coV-2[15]. Even so human body cell don't make spike protein, they can still read viral messenger RNA and follow its rules $[13,14]$. Spike protein generates by dose but only the spike protein and no other parts of the virus [13]. Human body cell has mRNA of genes for the spike protein on the surface of Covid 19. After the mRNA lipids of the synthetic mRNA is collection in a lipids nanoparticles that the instruction a cells membrane to cell [14]. The mRNA gives message to manufacture the viral protein. That surface of the cell and restoratives immune system feedback [12]. After this process antigen is formed and T cells are produced [16]. An mRNA vaccine is relatively new on the scene, but has the potential to be safe and more effective than other vaccine types. There is no risk of getting Covid 19 from a vaccine, as the virus is never present in the body [12].

\subsubsection{Clinical Trials Status}

Preclinical trial: In the preclinical study, BNT162b2 demonstrated protective antiviral effect in rhesus macaques, with concomitant high neutralizing antibody titers and a TH-1 based cellular response in rhesus macaques and mice [15]. In a Covid viral infection, macaques that received two control injections were challenged 55 days after the 2 nd immunization with very high viral inoculums of approximately, million plaque forming units of SARS -COV-2, via both nose and lungs routes $[15,16]$.

Phase I: After preclinical trials the vaccine passes for phases I trial and it will check the efficacy and safety of the trial is the animals so that animals will developed strong immune system it will be help to found out it was suitable for humans being and or not [15]. 
Phase II-III: The final stage of the vaccine BNT162b2 began in late June and has enrolled 44,543 participants to date, 90 $\%$ of who have received a second dose of the vaccine candidate as of December 2020[16]. The phase 2-3 study is an event driven trial that is planned to enroll up to 40,000 participants between 18 to 85 years of ages [13].

\subsection{ZycoV-D Vaccine}

ZycoV-D vaccine is the India's second vaccine candidate to start the human trials \& developed by the Institute of ZydusCadila $[17,19]$. It consists of the genetic material of SARS coV-2 proteins that human cells to make a SARScoV-2 antigen and will inform to immune response.

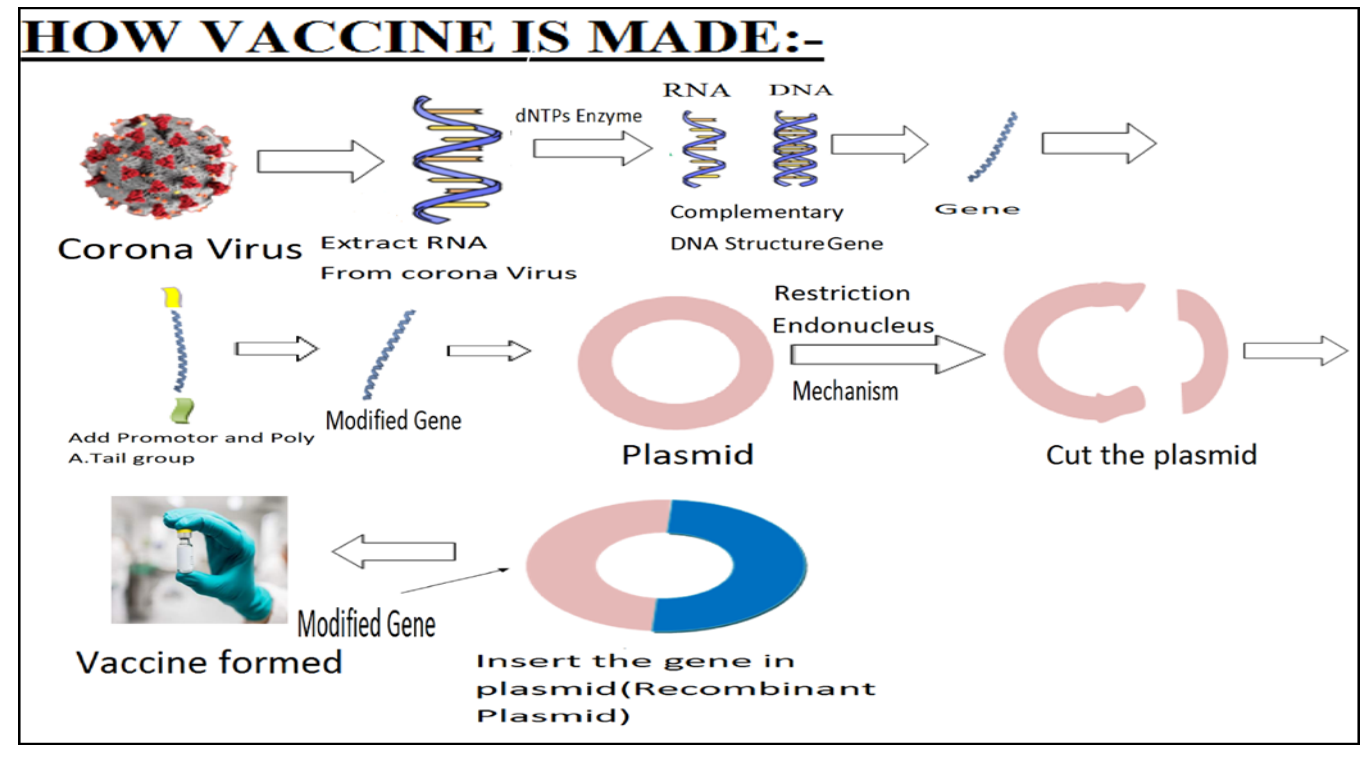

Figure 1 (a)Development of ZycoV-D vaccine.

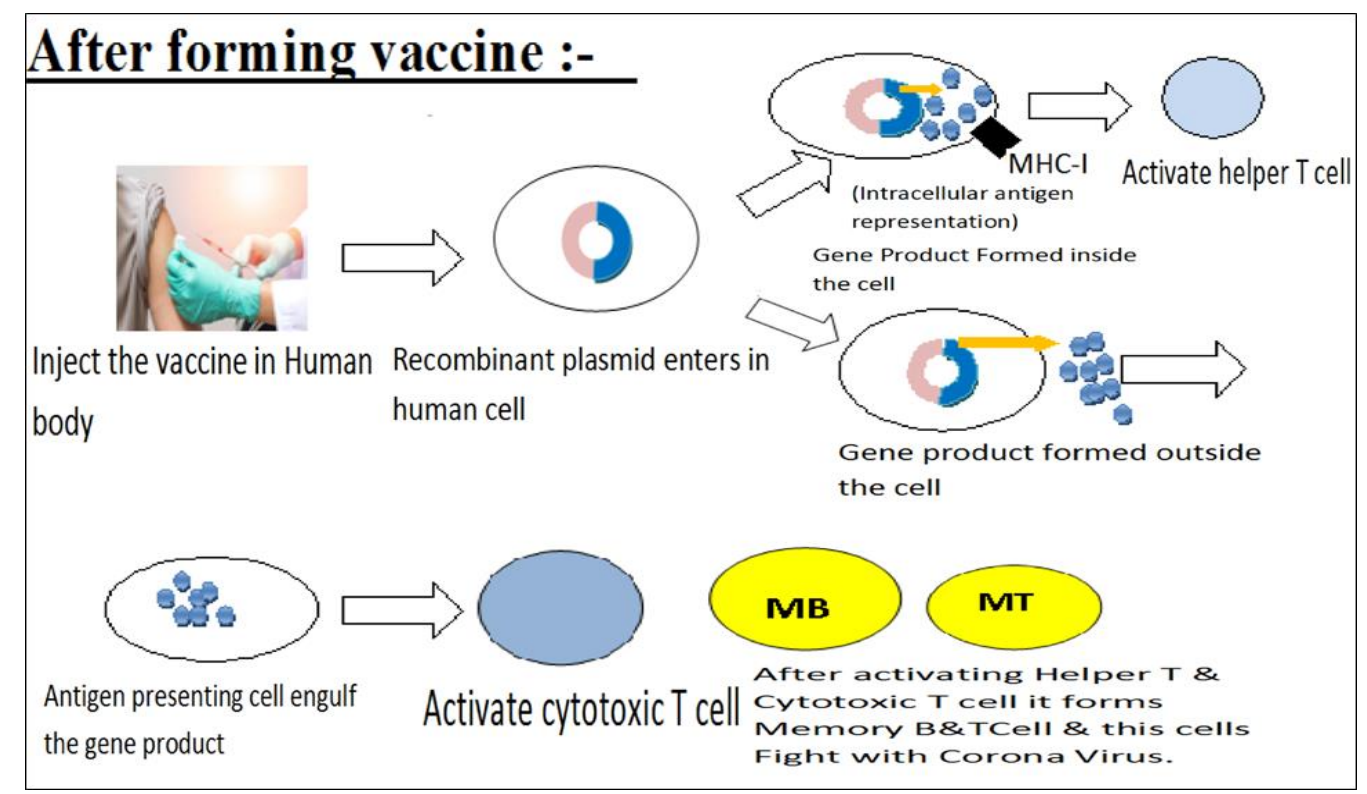

Figure 1(b)Formation of T cell for destroying Covid -19 virus.

\subsubsection{Mechanism}

This vaccine can be developed by plasmid DNA Vaccine. It will developed DNA vaccine by viral proteins and it is present on virus [17]. Extract the RNA from corona Virus and forming a complementary DNA structure by dNTPs (Deoxynucleoside triphosphates). This Complementary DNA structure is the gene in which add the promoter and Poly A. tail group. Promoter is made up of two main regions coding region and non coding region. Coding region is used for the formation of gene product, and Non-coding region is used for the Controlling of transcription of coding region. 
Promoter is added in the gene because gene works well in human cell. Also added the poly A. tail group because in prokaryotic cell the messenger RNA is formed but it not move in the cell but in case of eukaryotic cell the messenger RNA is move from nucleus to cytoplasm by various enzymes \& this enzymes are very harmful. After modifying the gene cut the plasmid by Restriction endonucleus mechanism and inserts the modified gene in Plasmid, it is called as recombinant plasmid. After formation of one recombinant plasmid makes copies by PCR and formed a vaccine. Inject the vaccine to human body by needles, gene gun, $\mathrm{CO} 2$ Bioinjector, Electroportation. Injecting the vaccine in human body, the recombinant plasmid enters in the human cell and forming the gene product inside, outside the cell. Gene product formed inside the cell it represents as a MHC-I (Intracellular antigen representation) \& activate the helper T cell. Gene product formed outside the cell, \& engulfs by the antigen presenting cell it represents as a MHC-II (Extracellular antigen representation) \& activate the Cytotoxic T cell. Helper T cell and Cytotoxic T cell forms the memory B cell and memory $\mathrm{T}$ cell which can formed a strong immune system and fight against corona virus.

\subsubsection{Clinical Trials Status}

Preclinical trial: After developing the vaccine it will be passes for preclinical trials at which it will be performed the vaccine trials on animals. The rats, guinea pigs, rabbits, mouse can participated in trials [20]. For two animals take a 28 days' time for vaccine trial. In this trial it will check the efficacy and safety of the vaccine candidate. The result of the trial is the pigs, rabbit's animals devolved the strong immune system it will be help to induce the high level of neutralizing antibodies in animals, vaccine demonstration for favorable studies also, and it will check the tolerability [17]. Phase I: After preclinical trial the vaccine passes to DCGI for phase I trial on human consists of 1000 volunteers participated for vaccine trial $[19,20]$. The result for phase I is this vaccine developed the antibodies amount check by antibody titer test in which the person's blood calculate the strength of the immune response [18]. Phase II and III: In this phase II 1000 volunteers can be participating and this trial conduct on Nov- Dec 2020 [19].

\subsection{SARS Cov2 Vaccine (AZD1222)}

AZD1222 vaccine was come about by Oxford University "Jenner Institute and Oxford Vaccine group [21, 22, 23]. The AZD1222 corona vaccine knows as ChAdox 1n Cov-19 is made from Chadox125. Its Vaccines needs to kept that 2-8 ${ }^{\circ} \mathrm{C}$ (For at least 6 months) [21]. New version of a common cold virus (adeno virus) that causes due to Chimpanzee [21, 25].

\subsubsection{Mechanisms}

AZD1222 Vaccine it works by use viral vector (syndrome) and produced T cells [22, 24, 25]. After vaccination spike protein produced in human body [22]. Immune system attacks on virus, if it later infects the body protect it against Covid -19 through body [25]. In the immune system of a healthy volunteers is strong and the body induced large amount of T-cells [25, 26]. AZD1222 vaccine develop by generate immunity power to the body [26]. After get vaccination power generates human body they affected as spike protein gene is purified [22]. Then next step genetic material added through AZD1222 they body produce spike protein. AZD1222 vaccination produced Antibodies through the healthy volunteer's body [21].

\subsubsection{Clinical Trials Status}

Trail phase I/II start in country Southern England on 2020 April 23 [21]. Healthy Volunteers (1077) age group of 18 to 55 years $[22,23,25]$. Across the southern centers, the centers AZD1222 vaccine access safety, immunogenicity and efficacy $[25,26]$. In the trial 543 participate received First dose, AZD1222 (and 56 volunteers also received Prophylactic Paracetamole), and next 534 volunteers received MenAcWY, a comparator meininological conjugate vaccine. 10 Volunteers received two dose AZD1222 vaccines a part of 1 month [25]. AZD1222 vaccine single dose results are very good and appreciate in volunteers $[22,25]$. After vaccination produce foure-fold antibodies increase to the SARS-CoV2 , then Virus spike proteins in 95\% of volunteers one month after apply vaccination AZD1222 [21, 25]. Mainly on healthy volunteers researched observed that T-Cell response was induced by 14 day and good T-Cell response, after 2 months vaccinations $[22,23]$. Researcher told that no serious effect produced AZD1222 and reactions were less the use of prophylactic paracetamole tablet [25]. And 328 volunteers received AZD1222 without paracetamole (67\%) reported mild to moderate pain after vaccinations and 403 (83\%) volunteers reported site tenderness [25]. AZD1222 without paracetamole group added the observed systematic reaction were common in volunteers [21, 22]. After vaccinations $340(70 \%)$ reporting volunteers fatigue and 31 (68\%) reported headache after get AZD1222. Other reaction reported the group includes muscle aches (60\%), malaise (61\%) chills (56\%) and feeling feverish (51\%) and other are experienced Fever, $18 \%$ reported temperatures of at least $38 \%$ and $2 \%$ reported temperature at least 39 degree Celsius. Systematic reaction was highest on and after vaccination AZD1222. After protective responses through l/2 phase then next phase automatically approval by FDA [22, 24]. II/III phase trial centers UK and Brazil $[21,22,23]$. 


\subsection{Sputnik -V vaccine (Gam-kOVID-Vak)}

The Gam-kOVID-Vak Vaccine was developed by Gamaleya Research Institute of Epidemiology and Microbiology [27, 29]. 11 Aug 2020 Registered Vaccines COVID -19 By the Russian Ministry of Health27. Is the first world country quick approval Sputnik V (Gam-kOVID-Vak) in order to claim to production COVID-19 Vaccine [27, 29]. After a good response vaccine developers claim that it to be best vaccine COVID-19 and recently World Health Organization present [27]. List and this vaccine (Gam-kOVID-Vak) among top 10 candidate vaccine approaching end of clinical trial and start the large amount of vaccine production [27].

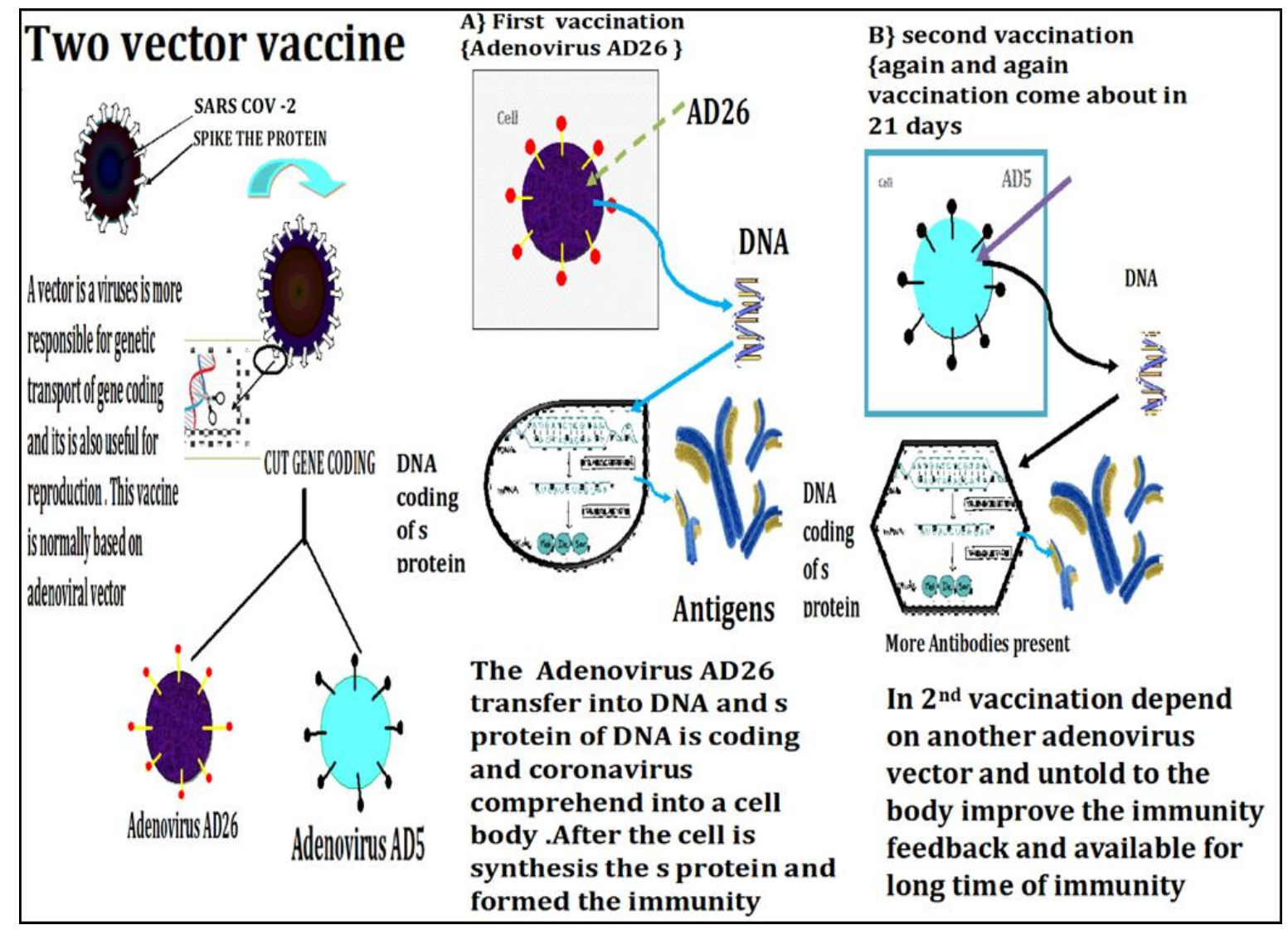

Figure 2 Method of developing vaccine.

\subsubsection{Mechanism}

Sputnik v (Gam-kOVID-Vak) is based on viral two vector vaccine, the human adenovirus -a -common cold virus - (rAD5 C, $\operatorname{rAd} 26[27,29]$. Steps after vaccination: Sputnik V (Gam-kOVID-Vak) Vaccine binding with the gene that encoding. The spike protein of SARS-CoVID-2 (Novel Corona Virus) to stimulate an immunity response [27, 28, 29]. In vaccine, the recombinant adenovirus type -5 (AD-5) and adenovirus type -26 (Ad26), used as vector in the vaccine and immunity response [27]. 1st Day vaccination: Vector with gene Coding S proteins of Corona virus gets into a cell. The body synthesizes $S$ proteins in response the production of immunity Response [29]. 21st Day vaccination: The vaccine based on another adenovirus vector unknown to the body boost the immune for long testing immunity [29].

\subsubsection{Clinical Trials Status}

Phase $1 / 2$ clinical trials of the Russian countries officially registered COVID-19 vaccine Sputnik V [27]. According to result phase $1 / 2$ vaccine are safe and effective, strong antibody and cellular immune response. After vaccination to healthy volunteers the observed that $\mathrm{T}$-Cells and immunity boost response [27]. Then also RDIF said that the level of neutralizing antibodies with the vaccine (Gam-COVID-Vak) was 1.4 to 1.5 times higher compared to those patients who had recovered Form COVID -19 [27, 28]. After l/2 clinical trial according to good result by healthy volunteers [29]. RDIF start the phase $2 / 3$ trial on Belarus, UAE, Venezuela and other Countries, while it is a phase $2 / 3$ in India. According to result phase 2/3 trial Sputnik V 92\% effective, show interim trial result [28]. Earlier the in this month's Russian said that 40000 volunteers as a part of it is large phase 3 Trials. experience from phase 1 and 2 [27]. 


\subsection{Covaxin}

Covaxin is the India's first Indigenous Covid-19 vaccine and developed by the Bharat biotech International Limited collaborated with National Institute of Virology (NIV) [30,32]. Alhydroxiquim-II adjuvant drug used to boost immune response. We use adjuvant that elucidate mechanisms of action inducing greater antibodies response to vaccine antigens and provide protection against pathogens [30]. Also adjuvant will enhance the sustainability for vaccine to provide antigens sparing effect [30]. The reason behind developing the vaccine is to recognized your immunity system and fight with novel corona virus in our body being at risks of an actual infection33.

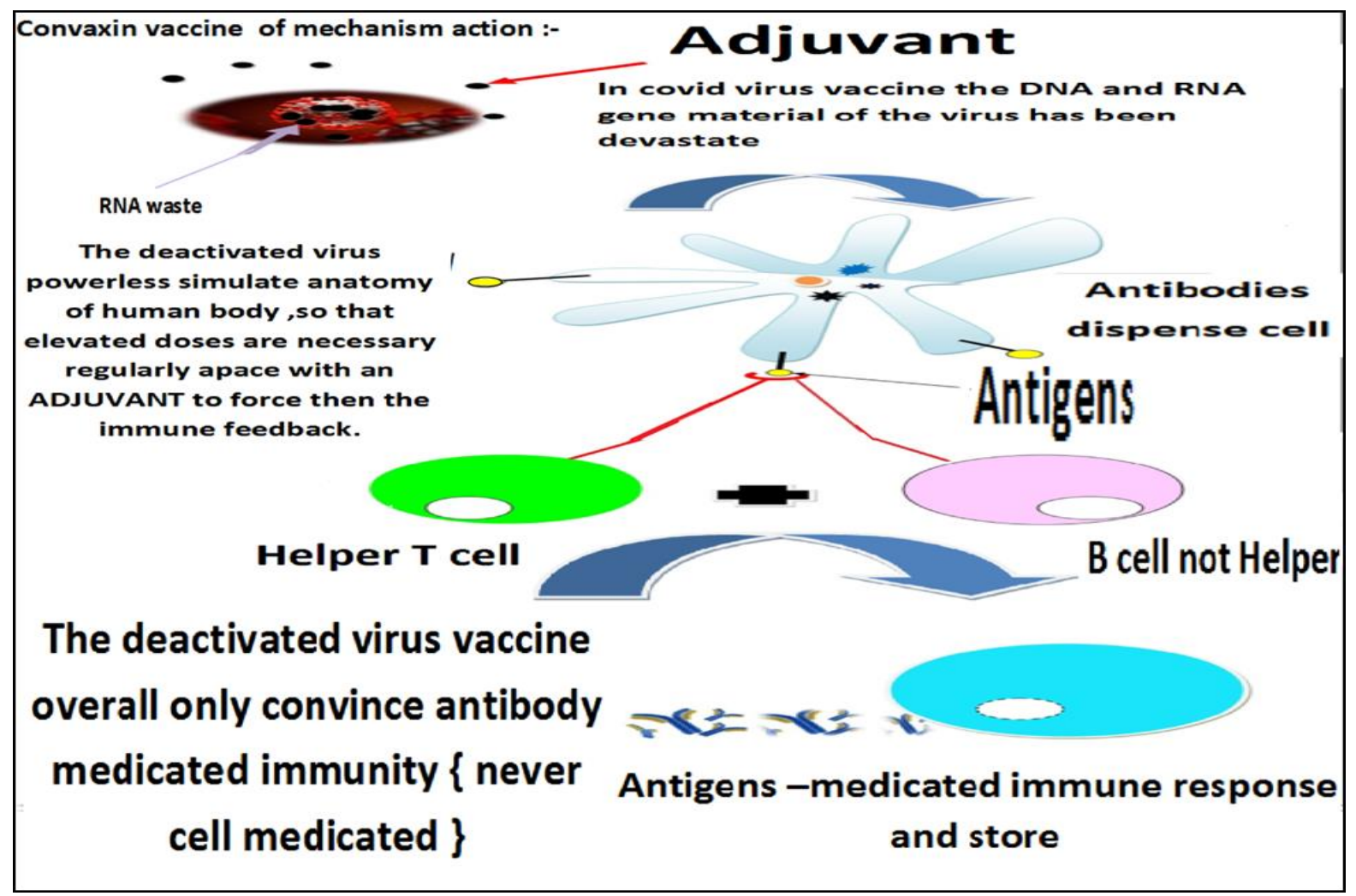

Figure 3 Formation of antibodies dispenser

\subsubsection{Mechanism}

Covaxin is the inactivated vaccine \& enhances the antibody response [30, 31]. In that vaccine the dead virus is used \& genetic material RNA, DNA present in the virus that has been destroyed. After destroying the genetic material the vaccine injects in the human cell by injections and there it has no potential to replicate or infect inside the body and needed the higher doses [30]. Also use adjuvant (Alhydroxiquim-II) to strong the immune response.

\subsubsection{Clinical Trials Status}

Preclinical trial: After producing the vaccine BBIL passes this vaccine to preclinical trial in animals [30]. Preclinical trial will be conducted on animal such as mice, guinea pigs and results to be seen as the news say for years and it boosts the immunity response and preventing to any infection or diseases [30].

Phase-I: after pre clinical trial CDSCO approving the coaxin for human trial on phase I [30]. This trial conduct at small group of people and the people can be divided in a four groups. First three groups will receive the coaxin vaccine but fourth group can receive the Japanese encephalitis vaccine that would be previously developed and this fourth group called as a controller group [33]. The people divided in four group because to see the comparable property to other vaccine and good effects of the coaxin vaccines [33]. Phase-I trial results it will check the Covaxin is safe for use and the rate of effectiveness of their immunity towards the virus [33].

Phase-II: In phase -II trial around 750 to 800 people are participated in this trial and this trial will be conducted same as in phase-I means conducted in four groups [33]. In phase-II trial it will check the Covaxin vaccine ability to enhance necessary immunity response towards novel corona virus [33]. 
Phase-III: after performing the phase-II trial around 26,000 people are participated in this trial [32]. Approximately 22 sites such as Delhi, Haryana, and Odisha in the country started phase-III on 16th November [32].

\section{Lists of covid 19 vaccines}

Table 2Brief information of different vaccines and stages of clinical trial.

\begin{tabular}{|c|c|c|c|c|c|c|}
\hline Agents & Sponsor & $\begin{array}{l}\text { Mechanisms } \\
\text { action }\end{array}$ & Institute & $\begin{array}{l}\text { Trial } \\
\text { phase }\end{array}$ & $\begin{array}{l}\text { Country } \\
\text { [critical } \\
\text { trial] }\end{array}$ & Refrencene \\
\hline $\begin{array}{l}\text { Bacillus } \\
\text { calmette } \\
\text { Guerin } \\
\text { [BCG] } \\
\text { vaccine }\end{array}$ & $\begin{array}{l}\text { i.university of } \\
\text { Melbourne and } \\
\text { Murdoch } \\
\text { children } \\
\text { research } \\
\text { institute } \\
\text { [austrelia ] } \\
\text { ii.Rodboud } \\
\text { university } \\
\text { medical } \\
\text { center } \\
\text { [nethorland ] } \\
\text { iii.Faustomon } \\
\text { Labatt } \\
\text { Massachusetts } \\
\text { General hospital } \\
\text { [America ] }\end{array}$ & $\begin{array}{l}\text { Live } \\
\text { attenuated } \\
\text { vaccine }\end{array}$ & $\begin{array}{l}\text { 1.university of } \\
\text { Melbourne and } \\
\text { Murdoch } \\
\text { children } \\
\text { research } \\
\text { institute } \\
\text { [Australia ] } \\
\text { 2.Rodboud } \\
\text { university } \\
\text { medical center } \\
\text { [nethorland ] } \\
\text { 3.Faustomon } \\
\text { Labatt } \\
\text { Massachusetts } \\
\text { General hospital } \\
\text { [America ] }\end{array}$ & $\begin{array}{l}\text { Phase } \\
2 / 3\end{array}$ & Japan & $\begin{array}{l}\underline{\text { https://scholar.goo }} \\
\text { gle.co.in/scholar?q }= \\
\text { bacillus+calmette+g } \\
\text { uerin+vaccine\&hl=e } \\
\text { n\&as sdt=0\&as vis } \\
\text { =1\&oi=scholart }\end{array}$ \\
\hline $\begin{array}{l}\text { India } \\
\text { imunolog } \\
\text { ides }\end{array}$ & $\begin{array}{l}\text { Hyderabad } \\
\text { headquartered }\end{array}$ & $\begin{array}{l}\text { Use of an } \\
\text { innovative } \\
\text { codon - } \\
\text { deoptimizatio } \\
\text { n tech }\end{array}$ & $\begin{array}{l}\text { 1.indian } \\
\text { immunologidest } \\
\text { td [IIL] } \\
\text { 2.Griffth } \\
\text { university } \\
\text {,Australia }\end{array}$ & Phase 3 & India & $\begin{array}{l}\text { https://m.hindusta } \\
\text { ntimes.com/india- } \\
\text { news/7-indian- } \\
\text { firms-in-race-to- } \\
\text { develop-covid-19- } \\
\text { vaccine-who- } \\
\text { stands- } \\
\text { where/story- } \\
\text { KKiXGhuhkPTki5Zt } \\
\text { M0YshN.html }\end{array}$ \\
\hline HGC019 & $\begin{array}{lr}\text { i.Gennova } & \\
\text { ii.Hdtbioin } & \text { us, } \\
\text { Brazil and } \\
\text { southafrica }\end{array}$ & $\begin{array}{l}\text { mRNA recreat } \\
\text { the covid }-19 \\
\text { spike protein }\end{array}$ & $\begin{array}{l}\text { Gennova } \\
\text { biopharmaceutic } \\
\text { al -HDT bio }\end{array}$ & $\begin{array}{l}\text { Started } \\
\text { clinical } \\
\text { trial }\end{array}$ & USA & $\begin{array}{l}\text { https://gennova.bi } \\
\text { o/mrna-vaccines/ }\end{array}$ \\
\hline $\begin{array}{l}\text { LUNAR - } \\
\text { COVID } 19 \\
\text { [ARCT- } \\
\text { 021] }\end{array}$ & $\begin{array}{l}\text { i.ArcturusThera } \\
\text { putics Inc. } \\
\text { ii.Duke-NVS }\end{array}$ & $\begin{array}{l}\text { Self } \\
\text { replicating } \\
\text { RNA vaccine }\end{array}$ & $\begin{array}{l}\text { Arcturus } \\
\text { Therapeutics } \\
\text { and DukeNUs } \\
\text { medical school }\end{array}$ & Phase2 & Singapore & $\begin{array}{l}\underline{\text { https://m.economic }} \\
\underline{\text { times.com/news/in }} \\
\text { ternational/busines } \\
\text { s/singapore- } \\
\text { developed-covid- } \\
\underline{\text { 19-vaccine- }} \\
\text { injected-into-first- } \\
\text { group-of- } \\
\text { volunteers/articles } \\
\underline{\text { how/77524083.cm }} \\
\underline{\text { s }}\end{array}$ \\
\hline
\end{tabular}




\begin{tabular}{|c|c|c|c|c|c|c|}
\hline $\begin{array}{l}\text { LNP-n } \\
\text { COVsa } \\
\text { RNA }\end{array}$ & $\begin{array}{l}\text { Imperial college } \\
\text { of London }\end{array}$ & $\begin{array}{l}\text { Self } \\
\text { amplifying } \\
\text { RNA vaccine }\end{array}$ & $\begin{array}{l}\text { Imperial college } \\
\text { of London }\end{array}$ & Phase 2 & England & $\frac{\underline{\text { https://go.drugban }}}{\text { k.com/drugs/DB15 }}$ \\
\hline $\begin{array}{l}\text { bacTRL- } \\
\text { spike }\end{array}$ & Symviva & $\begin{array}{l}\text { Monovalent } \\
\text { oral vaccine } \\
\text { [bifidobacteri } \\
\text { a ] }\end{array}$ & $\begin{array}{l}\text { Symvivo } \\
\text { corporation }\end{array}$ & Phase 1 & Canada & $\begin{array}{l}\text { https://www.genen } \\
\text { gnews.com/covid- } \\
\text { 19- } \\
\text { candidates/symviv } \\
\text { o-bactrl-spike/ }\end{array}$ \\
\hline GX-19 & Genexine Inc. & DNA Vaccine & Genexine Inc. & Phase2 & Korea & $\begin{array}{l}\underline{\text { https://clinicaltrial }} \\
\text { s.gov/ct2/show/NC } \\
\text { T04445389 }\end{array}$ \\
\hline $\begin{array}{l}\text { Adimrsc - } \\
2 \mathrm{f}\end{array}$ & Adimmune & $\begin{array}{l}\text { Protci subunit } \\
\text { vaccine }\end{array}$ & Adimmune & Phase 1 & $\begin{array}{l}\text { Taiwanes } \\
\mathrm{e}\end{array}$ & $\begin{array}{l}\text { https://www.raps.o } \\
\text { rg/news-and- } \\
\text { articles/news- } \\
\text { articles/2020/3/co } \\
\underline{\text { vid-19-vaccine- }} \\
\text { tracker }\end{array}$ \\
\hline $\begin{array}{l}\text { Epivac } \\
\text { corona }\end{array}$ & $\begin{array}{l}\text { Federal } \\
\text { Budgetary } \\
\text { Research } \\
\text { institution state } \\
\text { research center } \\
\text { of virology and } \\
\text { biotechnology }\end{array}$ & $\begin{array}{l}\text { Peptide } \\
\text { vaccine }\end{array}$ & $\begin{array}{l}\text { Federal } \\
\text { Budgetary } \\
\text { Research } \\
\text { institution state } \\
\text { research center } \\
\text { of virology and } \\
\text { biotechnology }\end{array}$ & Phase 2 & Russia & $\begin{array}{l}\underline{\text { https://www.precis }} \\
\text { ionvaccinations.co } \\
\text { m/vaccines/epivac } \\
\underline{\text { corona-vaccine }}\end{array}$ \\
\hline Sputnikv & $\begin{array}{l}\text { Gamaleya } \\
\text { Research } \\
\text { institute } \\
\text {,acellena } \\
\text { contract drug } \\
\text { research and } \\
\text { dev }\end{array}$ & $\begin{array}{l}\text { Non } \\
\text { replicating } \\
\text { viral vector }\end{array}$ & $\begin{array}{l}\text { Various institute } \\
\text { work on this } \\
\text { vaccine }\end{array}$ & Phase 3 & Russia & $\begin{array}{l}\text { https://en.m.wikip } \\
\text { edia.org/wiki/Gam- } \\
\underline{\text { COVID-Vac }}\end{array}$ \\
\hline $\begin{array}{l}\text { AG0301 - } \\
\text { COVID } 19\end{array}$ & AnGes ,Increse & DNA vaccine & $\begin{array}{l}\text { Japan agency for } \\
\text { medical research } \\
\text { and } \\
\text { development }\end{array}$ & Phase 2 & Japan & $\begin{array}{l}\underline{\text { https://biorender.c }} \\
\text { om/covid-vaccine- } \\
\text { tracker/details/v- } \\
\underline{\text { CV28/-43 }}\end{array}$ \\
\hline INO-4800 & $\begin{array}{l}\text { Inoviopharmace } \\
\text { tical }\end{array}$ & $\begin{array}{l}\text { DNA vaccine } \\
\text { [plasmid] }\end{array}$ & $\begin{array}{l}\text { Center for } \\
\text { pharmaceticalre } \\
\text { search,kanvascit } \\
\text { y, Univeristy of } \\
\text { Pennsylvania } \\
\text {,Philadelphia }\end{array}$ & Phase3 & America & $\begin{array}{l}\underline{\text { https://www.precis }} \\
\text { ionvaccinations.co } \\
\underline{\text { m/vaccines/ino- }} \\
\text { 4800-dna- } \\
\text { coronavirus- } \\
\text { vaccine }\end{array}$ \\
\hline $\begin{array}{l}\text { INI - } \\
7843673 \\
5 \\
\text { [formerly } \\
\text { AD26 CoV } \\
2-5 \text { ] }\end{array}$ & $\begin{array}{l}\text { Johson and } \\
\text { Johnson }\end{array}$ & $\begin{array}{l}\text { Non- } \\
\text { replicating } \\
\text { viral vector }\end{array}$ & $\begin{array}{l}\text { Johson and } \\
\text { Johnson }\end{array}$ & Phase 3 & America & $\begin{array}{l}\text { https://www.precis } \\
\text { ionvaccinations.co } \\
\text { m/vaccines/ad26co } \\
\underline{\text { v2-s-vaccine }}\end{array}$ \\
\hline $\begin{array}{l}\text { mRNA } \\
1273\end{array}$ & Moderna & $\begin{array}{l}\text { mRNA based } \\
\text { vaccine }\end{array}$ & $\begin{array}{l}\text { Kaiser } \\
\text { permanentewas } \\
\text { hington health } \\
\text { research } \\
\text { instituent }\end{array}$ & Phase 3 & America & $\begin{array}{l}\text { https://www.mode } \\
\text { rnatx.com/modern } \\
\text { as-work-potential- } \\
\text { vaccine-against- } \\
\text { covid-19 }\end{array}$ \\
\hline
\end{tabular}


World Journal of Advanced Research and Reviews, 2021, 10(01), 143-155

\begin{tabular}{|c|c|c|c|c|c|c|}
\hline $\begin{array}{l}\text { NOVA } \\
\text { VAX [NVX } \\
- \\
\text { COV2373] }\end{array}$ & Novavax,Takeda & $\begin{array}{l}\text { Non partical } \\
\text { vaccine }\end{array}$ & Novavax & Phase 3 & America & $\begin{array}{l}\text { https://ir.novavax.c } \\
\text { om/news- } \\
\text { releases/news- } \\
\text { release- } \\
\text { details/novavax- } \\
\text { covid-19-vaccine- } \\
\text { granted-fast-track- } \\
\text { designation-us-fda }\end{array}$ \\
\hline BNT 162 & $\begin{array}{l}\text { i.Biontech SE } \\
\text { ii.pfizer } \\
\text { iii.shanghaifosu } \\
\text { npharmaceutica } \\
\text { lDevlopmentco, } \\
\text { Ltd }\end{array}$ & $\begin{array}{l}\text { mRNA based } \\
\text { vaccine }\end{array}$ & $\begin{array}{lr}\text { Multiple } & \text { study } \\
\text { sites in } & \text { Europe } \\
\text { and } & \text { north } \\
\text { America } & \end{array}$ & Phase 3 & America & $\begin{array}{l}\text { https://www.pfizer } \\
\text { com/news/press- } \\
\text { release/press- } \\
\text { release- } \\
\text { detail/pfizer-and- } \\
\text { biontech-conclude- } \\
\text { phase-3-study- } \\
\text { covid-19-vaccine }\end{array}$ \\
\hline $\begin{array}{l}\text { BBIBP - } \\
\text { CorV }\end{array}$ & $\begin{array}{l}\text { Beijing institute } \\
\text { of biological } \\
\text { produets china } \\
\text { National pharm. } \\
\text { Grp [sinopharm] }\end{array}$ & $\begin{array}{l}\text { Inactivated } \\
\text { vaccine }\end{array}$ & $\begin{array}{l}\text { Henan } \\
\text { provincial center } \\
\text { for disease } \\
\text { control and } \\
\text { prevention }\end{array}$ & Phase 3 & China & $\begin{array}{l}\text { https://www.scien } \\
\text { cedirect.com/scienc } \\
\text { e/article/pii/S0092 } \\
\underline{867420306954}\end{array}$ \\
\hline $\begin{array}{l}\text { Ad5-n- } \\
\text { cov }\end{array}$ & cansin biologics & $\begin{array}{l}\text { Recombinant } \\
\text { vaccine } \\
\text { [adenovirus } \\
\text { type svedo ] }\end{array}$ & Tongi hospital & Phase 3 & China & $\begin{array}{l}\underline{\text { https://www.raps.o }} \\
\text { rg/news-and- } \\
\text { articles/news- } \\
\text { articles/2020/3/co } \\
\text { vid-19-vaccine- } \\
\underline{\text { tracker }}\end{array}$ \\
\hline $\begin{array}{l}\text { Corona } \\
\text { vac }\end{array}$ & Sinovac & $\begin{array}{l}\text { Inactivated } \\
\text { vaccine }\end{array}$ & $\begin{array}{l}\text { Sinovac research } \\
\text { and } \\
\text { development } \\
\text { co,Ltd }\end{array}$ & Phase 3 & China & $\begin{array}{l}\text { https://en.m.wikip } \\
\underline{\text { edia.org/wiki/Coro }} \\
\underline{\text { naVac }}\end{array}$ \\
\hline AZD1222 & $\begin{array}{l}\text { The university } \\
\text { oxford : Astra } \\
\text { Zaneca ;IQVIA ;- } \\
\text { SERUM institute } \\
\text { of india }\end{array}$ & $\begin{array}{l}\text { Replication } \\
\text { deficient viral } \\
\text { vector } \\
\text { vaccine }\end{array}$ & $\begin{array}{l}\text { The university of } \\
\text { oxford the } \\
\text { jenner institute }\end{array}$ & Phase 3 & India & $\begin{array}{l}\underline{\text { https://en.m.wikip }} \\
\underline{\text { edia.org/wiki/AZD }} \\
\underline{1222}\end{array}$ \\
\hline $\begin{array}{l}\text { Hydroxyc } \\
\text { hlorquine }\end{array}$ & $\begin{array}{l}\text { i.University of } \\
\text { Oxford } \\
\text { ii.University of } \\
\text { Minnesota } \\
\text { iii.University of } \\
\text { Washington } \\
\text { iv.Nacionaldecol } \\
\text { ombia }\end{array}$ & $\begin{array}{l}\text { Antimalerial } \\
\text { drug against } \\
\text { Covid-19 }\end{array}$ & $\begin{array}{l}\text { Various Institute } \\
\text { work on this } \\
\text { drug }\end{array}$ & Phase4 & India & $\begin{array}{l}\text { https://www.medic } \\
\text { overhospitals.in/co } \\
\text { ronavirus/hydroxy } \\
\text { chloroquine/ }\end{array}$ \\
\hline $\begin{array}{l}\text { Remedesi } \\
\text { vir }\end{array}$ & $\begin{array}{l}\text { i.Gilead ,world } \\
\text { Health org. } \\
\text { SOLIDARITY } \\
\text { Trial } \\
\text { ii. National } \\
\text { Institute of } \\
\text { Allergy } \quad \& \\
\text { Infectious } \\
\text { disease }\end{array}$ & Antiviral drug & $\begin{array}{l}\text { Various Institute } \\
\text { work on this } \\
\text { drug }\end{array}$ & Phase3 & $\begin{array}{l}\text { South } \\
\text { Asia }\end{array}$ & $\begin{array}{l}\underline{\text { https://www.meds }} \\
\text { cape.com/answers/ } \\
\text { 2500114- } \\
\text { 197451/what-is- } \\
\text { the-role-of-the- } \\
\text { antiviral-drug- } \\
\text { remdesivir-in-the- } \\
\text { treatment-of- } \\
\text { coronavirus- }\end{array}$ \\
\hline
\end{tabular}




\begin{tabular}{|c|c|c|c|c|c|c|}
\hline & & & & & & $\frac{\text { disease-2019- }}{\text { covid-19\#qna }}$ \\
\hline $\begin{array}{l}\text { Favipiavi } \\
\mathrm{r}\end{array}$ & $\begin{array}{l}\text { i.Fujifilm } \\
\text { Toyama } \\
\text { Pharmaceuticals } \\
\text { ii.Zheijian } \\
\text { University } \\
\text { school of } \\
\text { medicine } \\
\text { iii.ZhongnanHos } \\
\text { pital of Wuhan } \\
\text { University }\end{array}$ & $\begin{array}{l}\text { Antiviral } \\
\text { Drug }\end{array}$ & $\begin{array}{l}\text { Various institue } \\
\text { work on this } \\
\text { drug }\end{array}$ & Phase4 & Japan & $\frac{\underline{\text { https://www.ncbi.n }}}{\frac{\text { lm.nih.gov/pmc/art }}{L}}$ \\
\hline IMM101 & $\begin{array}{l}\text { i.Immodulon } \\
\text { Therapeutics } \\
\text { Ltd, BioCan Rx } \\
\text { ii.Canadian } \\
\text { Cancer Society } \\
\text { Research } \\
\text { Institute } \\
\text { (CCSRI) }\end{array}$ & $\begin{array}{l}\text { Marcolide } \\
\text { antibiotic } \\
\text { theraputic } \\
\text { drug }\end{array}$ & $\begin{array}{l}\text { Immodulon } \\
\text { Therapeutics } \\
\text { Ltd, BioCan Rx }\end{array}$ & Phase3 & $\begin{array}{l}\text { U.S,Canad } \\
\text { a }\end{array}$ & $\begin{array}{l}\text { https://www.ajmc. } \\
\text { com/view/drug- } \\
\text { that-boosts- } \\
\text { immunotherapy- } \\
\text { studied-as-tool-to- } \\
\text { battle-covid-19-in- } \\
\text { patients-with- } \\
\text { cancer }\end{array}$ \\
\hline $\begin{array}{l}\text { Measles, } \\
\text { Mumps\& } \\
\text { Rubella } \\
\text { vaccine }\end{array}$ & $\begin{array}{l}\text { i.Kasr El Aini } \\
\text { Hospital } \\
\text { ii.Louisiana } \\
\text { State University } \\
\text { Health Sciences } \\
\text { Center in New } \\
\text { Orleans } \\
\text { iii.Parsemus } \\
\text { Foundation }\end{array}$ & $\begin{array}{l}\text { Live } \\
\text { attenuated } \\
\text { vaccine }\end{array}$ & $\begin{array}{l}\text { Louisiana State } \\
\text { University } \\
\text { Health Sciences } \\
\text { Center in New } \\
\text { Orleans }\end{array}$ & Phase3 & $\begin{array}{l}\text { Egypt, } \\
\text { America, } \\
\text { Netherlan } \\
\text { d }\end{array}$ & $\begin{array}{l}\frac{\text { https://www.web }}{\text { md.com/lung/news }} \\
\text { L20200908/could- } \\
\text { the-mmr-vaccine- } \\
\text { help-prevent-covid- } \\
\text { 19-new-trial-may- } \\
\text { tell }\end{array}$ \\
\hline $\begin{array}{l}\text { KBP- } \\
\text { covid-19 }\end{array}$ & $\begin{array}{l}\text { Kentucky } \\
\text { Bioprocessing } \\
\text { Inc. }\end{array}$ & $\begin{array}{l}\text { Antigen } \\
\text { producine } \\
\text { vaccine }\end{array}$ & $\begin{array}{l}\text { Kentucky } \\
\text { Bioprocessing } \\
\text { Inc. }\end{array}$ & $\begin{array}{l}\text { Phase } \\
1 / 2\end{array}$ & U.S.,U.K. & $\begin{array}{l}\frac{\text { https://clinicaltrial }}{\text { s.gov/ct2/show/stu }} \\
\text { dy/NCT04473690 }\end{array}$ \\
\hline Ebastine & $\begin{array}{l}\text { Mjanyang } \\
\text { central Hospital }\end{array}$ & Antiviral drug & $\begin{array}{l}\text { Mjanyang } \\
\text { central Hospital }\end{array}$ & Phase4 & America & $\begin{array}{l}\underline{\text { https://biorender.c }} \\
\text { om/covid-vaccine- } \\
\text { tracker/details/v- } \\
\underline{0035 / \text { rna-mrna- }} \\
\underline{\text { cv07050101 }}\end{array}$ \\
\hline CoVLP & Medicago Inc. & $\begin{array}{l}\text { Virus like } \\
\text { particle based } \\
\text { vaccine }\end{array}$ & Medicago Inc. & $\begin{array}{l}\text { Phase } \\
2 / 3\end{array}$ & $\begin{array}{l}\text { Canada,U. } \\
\text { S., } \\
\text { America }\end{array}$ & $\begin{array}{l}\frac{\text { https://biorender.c }}{\text { om/covid-vaccine- }} \\
\text { tracker/details/v- } \\
\underline{0035 / \text { rna-mrna- }} \\
\text { cv07050101 }\end{array}$ \\
\hline INOpulse & $\begin{array}{l}\text { BellerophonReg } \\
\text { enero } \\
\text { pharmaceutical } \\
\text { Inc. }\end{array}$ & $\begin{array}{l}\text { INOpulse } \\
\text { device based } \\
\text { drug }\end{array}$ & $\begin{array}{l}\text { BellerophonReg } \\
\text { enero } \\
\text { pharmaceutical } \\
\text { Inc. }\end{array}$ & Phase 2 & $\begin{array}{l}\text { Warren,N } \\
\text { S, U.S. }\end{array}$ & $\begin{array}{l}\text { https://www.biow } \\
\text { orld.com/keywords } \\
\text { 113807-inopulse }\end{array}$ \\
\hline RTB101 & $\begin{array}{l}\text { RestorbioInc.,Na } \\
\text { tional } \\
\text { Institute of } \\
\text { Aging }\end{array}$ & $\begin{array}{l}\text { Inhibitory } \\
\text { drug }\end{array}$ & $\begin{array}{l}\text { RestorbioInc.,Na } \\
\text { tional } \\
\text { Institute of } \\
\text { Aging }\end{array}$ & Phase 2 & $\begin{array}{l}\text { California } \\
\& \text { Boston }\end{array}$ & $\begin{array}{l}\frac{\text { https://clinicaltrial }}{\text { s.gov/ct2/show/NC }} \\
\underline{\text { T04584710 }}\end{array}$ \\
\hline
\end{tabular}




\begin{tabular}{|c|c|c|c|c|c|c|}
\hline Sanofi & $\begin{array}{l}\text { i.Sanofi } \\
\text { ii.GSK }\end{array}$ & $\begin{array}{l}\text { Recombinant } \\
\text { DNA } \\
\text { Technology }\end{array}$ & Sanofi & $\begin{array}{l}\text { Phase1/ } \\
2\end{array}$ & French & $\begin{array}{l}\text { https://www.sanofi } \\
\text { com/en/about- } \\
\text { us/our- } \\
\text { stories/sanofi-s- } \\
\text { response-in-the- } \\
\text { fight-against-covid- } \\
\underline{19}\end{array}$ \\
\hline $\begin{array}{l}\text { Heat } \\
\text { biologics }\end{array}$ & $\begin{array}{l}\text { i.Heatbiologics,I } \\
\text { nc.(NASDAQ:HT } \\
\text { BX) } \\
\text { ii.waismanBiom } \\
\text { anufacturing }\end{array}$ & $\begin{array}{l}\text { Potential of } \\
\text { generating } \\
\text { long term } \\
\text { immune } \\
\text { responses }\end{array}$ & $\begin{array}{l}\text { Heat } \\
\text { Biologics,Inc. }\end{array}$ & Phase1 & U.S. & $\begin{array}{l}\text { https://www.heatb } \\
\text { io.com/news- } \\
\text { media/news- } \\
\text { releases/detail/669 } \\
\text { heat-biologics- } \\
\text { covid-19-vaccine- } \\
\text { demonstrates- } \\
\text { robust-t-cell }\end{array}$ \\
\hline $\begin{array}{l}\text { BNT162B } \\
2\end{array}$ & $\begin{array}{l}\text { i.BioNTech } \\
\text { ii.pfizer }\end{array}$ & $\begin{array}{l}\text { m-RNA based } \\
\text { vaccine }\end{array}$ & $\begin{array}{l}\text { Various Institute } \\
\text { works on this } \\
\text { vaccine }\end{array}$ & $\begin{array}{l}\text { After } \\
\text { phase3 } \\
\text { clinical } \\
\text { trial.It is } \\
\text { used in } \\
\text { an } \\
\text { emerge } \\
\text { ncy case }\end{array}$ & Germany & $\begin{array}{l}\underline{\text { https://en.m.wikip }} \\
\underline{\text { edia.org/wiki/BNT }} \\
\underline{162 \mathrm{~b} 2}\end{array}$ \\
\hline Nasovax & Altiimmune,Inc. & $\begin{array}{l}\text { Replication } \\
\text { deficient } \\
\text { adenovirus } \\
\text { vector } \\
\text { vaccine }\end{array}$ & Altiimmune,Inc. & Phase2 & U.S. & $\begin{array}{l}\text { https://clinicaltrial } \\
\text { s.gov/ct2/show/rec } \\
\text { ord/NCT04442230 }\end{array}$ \\
\hline Vaxart & $\begin{array}{l}\text { i.SOUTHSANFR } \\
\text { ANCISCO,Calif. } \\
\text { ii.Vaxart,Inc. }\end{array}$ & $\begin{array}{l}\text { Non } \\
\text { replicating } \\
\text { adenovirus } \\
\text { vaccine }\end{array}$ & NASDAQ:VXRT & Phase1 & America & $\begin{array}{l}\text { https://www.precis } \\
\text { ionvaccinations.co } \\
\text { m/vaccines/vaxart- } \\
\text { covid-19-oral- } \\
\underline{\text { vaccine }}\end{array}$ \\
\hline $\begin{array}{l}\text { Emergent } \\
\text { biosolutio } \\
\mathrm{n}\end{array}$ & $\begin{array}{l}\text { i.EmergentBioso } \\
\text { lution Inc. } \\
\text { ii.National } \\
\text { Institute } \\
\text { Allergy } \\
\text { \&Infectious } \\
\text { disease. } \\
\text { iii.Biomedicalad } \\
\text { vancedresearch } \\
\text { \&Devlopment } \\
\text { authority(BARD } \\
\text { A) }\end{array}$ & $\begin{array}{l}\text { Plasma based } \\
\text { hyperimmun } \\
\text { e vaccine }\end{array}$ & $\begin{array}{l}\text { Emergent } \\
\text { Biosolution Inc. }\end{array}$ & Phase3 & U.S. & $\begin{array}{l}\text { https://investors.e } \\
\text { mergentbiosolution } \\
\text { s.com/news- } \\
\text { releases/news- } \\
\text { release- } \\
\text { details/emergent- } \\
\text { biosolutions-covid- } \\
\text { 19-human- } \\
\text { immune-globulin- } \\
\text { product }\end{array}$ \\
\hline Geovax & $\begin{array}{l}\text { i.Geovax } \\
\text { ii.National } \\
\text { Institute } \\
\text { allergy } \\
\text { infectious } \\
\text { disease }\end{array}$ & $\begin{array}{l}\text { MVA-VLP } \\
\text { based vaccine }\end{array}$ & $\begin{array}{l}\text { NASDAQCM:GOV } \\
\text { X GOVXW }\end{array}$ & $\begin{array}{l}\text { Geovax } \\
\text { announc } \\
\text { es } \\
\text { license } \\
\text { aggrem } \\
\text { ent with } \\
\text { NIH to } \\
\text { support } \\
\text { continu } \\
\text { ed }\end{array}$ & U.S. & $\begin{array}{l}\underline{\text { https://adisinsight. }} \\
\text { springer.com/drugs } \\
\underline{\text { /800056835 }}\end{array}$ \\
\hline
\end{tabular}




\begin{tabular}{|l|l|l|l|l|l|l|}
\hline & & & $\begin{array}{l}\text { advance } \\
\text { ments in } \\
\text { vaccine } \\
\text { Devlop } \\
\text { ment }\end{array}$ & & \\
\hline Curevac & $\begin{array}{l}\text { Tubingen,Germ } \\
\text { anyHeadquarter } \\
\text { ed Biopharma } \\
\text { company }\end{array}$ & $\begin{array}{l}\text { m-RNA Based } \\
\text { Vaccine }\end{array}$ & $\begin{array}{l}\text { Tubingen,Germa } \\
\text { nyHeadquartere } \\
\text { d Biopharma } \\
\text { company }\end{array}$ & Phase2 & U.S. & $\underline{\frac{\text { https://www.bioph }}{\text { arma- }}}$ \\
$\frac{\text { reporter.com/Articl }}{\text { e/2020/11/12/Cur }}$ \\
$\frac{\text { eVac-flags-its- }}{\text { COVID-19-vacc }}$
\end{tabular}

\section{Future aspect drugs for covid-19}

There are some patents, therapeutic drugs, diagnostic agents being developed for the treatment of Covid-19. About $80 \%$ drugs can relative with development of therapeutic drugs, $28 \%$ can relative with diagnostic agents. There are some drugs in research and development for the treatment of Covid-19. There are some patents associated with potential drugs for treatment of Covid-19 like patent no. W02009114512 (Incyte Corporation, USA) and JP5971830 (Shionogi and Co, Ltd, Japan).

\section{Conclusion}

The corona virus (COVID -19) spreads at a clock wise time rate all over the world. The outbreak of the virus has confronted the world's economic medical and public health infrastructure. Currently, there are documented cure for the virus and many countries has been vaccine created and some vaccine $90 \%$ more effective. Covid -19 is an RNA virus that poses a threat to public health. Currently, the disease has caused thousands of infections and death. Fundament $100 \%$ no confirmed medicine or vaccine has been created to improve the health of patients with condition.

Prepare and study the general population to acceptance a Covid-19 vaccine with relatively lower effectiveness may be very difficult. Vaccine trials results bases allowing the candidate vaccine emergency use. Researcher finding out define of Covid-19 is immunological (immunity increase need) correlates of protection against novel corona virus, which could involve growing characteristics, age groups. The world human cannot be affordable any mistakes at the crucial juncture of the pandemic.

\section{Compliance with ethical standards}

\section{Acknowledgments}

I am thankful to all squad members for providing cooperative domain so that we could complete our work successfully.

\section{Disclosure of conflict of interest}

On behalf of all authors, the corresponding author states that there is no conflict of interest.

\section{References}

[1] Coronavirus. (2020, December 06). In Wikipedia.

[2] COVID-19 pandemic. (2020, December 09). In Wikipedia.

[3] Coronavirus disease. (2020, December 07). In Wikipedia. 2020.

[4] Coronavirus. World Health Organization (Health topics / Coronavirus). 2020.

[5] Coronavirus history. In Wikipedia. 2020.

[6] Shawna Williams, A Brief history of Humans coronavirus. In Wikipedia. June 2, 2020.

[7] Hong Kong flu. In Wikipedia. 7 December, 2020. 
[8] Influenza pandemic 1957-1958 (7 December, 2020). In Wikipedia.

[9] Spanish flu. In Wikipedia. 11 December, 2020.

[10] Pandemic influenza. In Wikipedia.

[11] News / Pfizer and BioNTech conclude phase 3 study COVID -19 vaccine candidate. November 18, 2020.

[12] Eric Sagonowsky, Angus Liu, Kyle Blankenship,conor Hale,FraiserKansteiner, COVID-19 tracker: Pfizer to file shot for full approval by April, exec says; Roche rolls out Elecsys antigen test in Europe. Dec 11, 2020.

[13] NEWS/ Pfizer and BioNTech Announce Data from Preclinical Studies of mRNA-based Vaccine Candidate Against COVID-19. September 09, 2020.

[14] Coronavirus disease (COVID-19): VACCINE. World Health organization. 28 October 2020.

[15] Brittney G. Borowiec,How does Pfizer's “90\% effective” COVID-19 vaccine work?,Wilfrid Laurier University. November 9, 2020.

[16] Adele peters, How Pfizer and Moderna's COVID-19 vaccines work: mRNA, World Health organization. 11 -092020.

[17] NEWS/ ZydusCadila's Covid-19 vaccine enters Phase II testing. 6th August 2020.

[18] NEWS/ PM Modi reaches Ahmedabad to review coronavirus vaccine development by ZydusCadila,November 28, 2020.

[19] NEWS/ Covid Vaccine: ZydusCadila completes phase-2 trial, to submit data in November. November 3, 2020.

[20] TIMES OF INDIA /Coronavirus Vaccine India: Covaxin, ZyCOV-D move to phase II clinical trials. August 6, 2020.

[21] AZD1222 vaccine met primary efficacy endpoint in preventing COVID-19. November 23, 2020.

[22] COVID-19 vaccine AZD1222 is better tolerated in older adults than younger adults with similar immune responses across all age groups. November 19, 2020.

[23] Reynald Castaneda, AstraZeneca's quick Covid-19 vaccine trial restart splits experts, GlobalData Health care. 12th Oct. 2020.

[24] AstraZeneca Study of COVID-19 Vaccine Candidate AZD1222. 27 october 2020.

[25] Pedro M Folegatti, Katie J Ewer, et. al. Safety and immunogenicity of the ChAdOx1nCoV-19 vaccine against SARSCoV-2: a preliminary report of a phase $1 / 2$, single-blind, randomized controlled trial, The Lancet journal. August15, 2020;396(10249): P467-478.

[26] Roadmap for evaluation of AstraZeneca AZD1222 Vaccine against Covid-19, World Health Organization. 30 October 2020.

[27] Gam -COVID -Vac, 0. In Wkipedia. 15 December, 2020.

[28] THE ECONOMIC TIMES, India trials for Russia's 'Sputnik-V' vaccine could start in next few weeks: Executive. September 22, 2020.

[29] Jacob koshy, The Hindu Explains | what do we know about Russia's COVID-19 vaccine candidate Sputnik V? September 22, 2020.

[30] Varinder Bhatia, Chandigarh, Anil Vij.tests positive, days after taking trial Covid-19 vaccine shot, Indian express News. December 6, 2020.

[31] NEWS,Anil Vij.on Covid-19 vaccine: Got only 1st shot of Covaxin, antibodies develop after 2nd dose. 06 Dec 2020.

[32] NEWS,Coronavirus vaccine in India: List of states that have started phase 3 trials of Covaxin. 02 Dec 2020.

[33] News/Coronavirus Outbreak, Coronavirus vaccine update: 2 vaccines could be eligible for emergency use in India by Jan, says AIIMS chief. 5 December 2020. 